\title{
Pemetaan Lahan Kritis Untuk Analisis Kesesuaian Pemanfaatan Lahan di Kabupaten Kulon Progo
}

\author{
Wirastuti Widyatmanti ${ }^{*}$, Sigit Heru Murti ${ }^{2}$, Prima Dinta Syam ${ }^{3}$ \\ 1,2,3 Program Diploma Penginderaan Jauh dan Sistem Informasi Geografi \\ Sekolah Vokasi, Universitas Gadjah Mada \\ *Email: wwidyatmanti@ugm.ac.id
}

\begin{abstract}
Abstrak
Perubahan penggunaan lahan jika tidak terkendali dan tidak didukung oleh upaya konservasi DAS yang baik akan memicu degradasi kualitas DAS, yang disebabkan oleh menurunnya fungsi lahan sebagai wilayah penyangga, baik dari aspek produksi dan ketersediaan air. Untuk itu perlu dilakukan upaya untuk meningkatkan kembali fungsi dan peruntukan lahan tersebut sehingga kualitas DAS kembali dalam kondisi yang seimbang dan lestari. Salah satu cara yang dapat dilaksanakan untuk melakukan pengaturan pemanfaatan lahan adalah melihat aspek kekritisan lahan pada wilayah. Penelitian ini bertujuan untuk memetakan lahan kritis yang terdapat di wilayah Kabupaten Kulon Progo menggunakan analisis data spasial dari interpretasi citra penginderaan jauh dan peta-peta tematik yang sudah ada; dan menganalisis keterkaitan antara pemanfaatan lahan eksisting terhadap lahan kritis yang ada. Analisis spasial dilakukan dengan menumpang-susunkan (overlay) beberapa data spasial (parameter penentu lahan kritis) untuk menghasilkan unit pemetaan baru yang akan digunakan sebagai unit analisis. Metode scoring mengakomodasi perbedaan tipe data parameter yang ada untuk menentukan tingkat kekritisan lahan. Hasil analisis menunjukkan bahwa di Kabupaten Kulon Progo 16.7\% atau 9541,21 ha dari luas wilayah kabupaten tersebut merupakan lahan yang tidak kritis, sedangkan $47.8 \%$ atau 27.397 ha merupakan lahan yang potensial kritis, atau jika tidak dikelola dengan baik bisa menjadi lahan kritis; dan 35,5\% atau 20,329 ha merupakan wilayah dengan status kekritisan lahan dari agak kritis, kritis hingga sangat kritis.
\end{abstract}

Kata kunci: $A L O S A V N I R$, pemetaan lahan kritis, overlay, kesesuaian pemanfatan lahan

\begin{abstract}
Uncontrolled and unsupported changes in land use by good watershed conservation efforts will lead to degradation of watershed quality, caused by declining land functions as buffer zones, both from production and water availability aspects. Therefore, efforts should be made to improve the function and land use so that the watershed quality is in a balanced and sustainable condition. One way that can be implemented to make land use arrangements is to look at the critical aspect of land in the region. This study aims to map critical lands in Kulon Progo regency using spatial data analysis from remote sensing image interpretation and existing thematic maps; and analyze the linkage between existing land use to existing critical land. Spatial analysis is done by overlaying some spatial data (critical land determinants) to generate a new mapping unit to be used as an analytical unit. The scoring method accommodates different types of parameter data available to determine the degree of criticality of the land. The result of the analysis shows that in Kulon Progo Regency $16.7 \%$ or 9541,21 ha from the area of the district is uncritical, while $47.8 \%$ or 27,397 ha is potentially critical land, or if not managed properly can become critical land; and 35.5\% or 20,329 ha are areas with land critical status from somewhat critical, critical to very critical.
\end{abstract}

Keywords: ALOS AVNIR, critical land mapping, overlay, suitability of land use 


\section{PENDAHULUAN}

Daerah Aliran Sungai (DAS) merupakan wilayah yang memiliki faktorfaktor penentu kualitas lingkungan dan lahan yang kompleks, baik di wilayah bagian hulu, tengah maupun hilir. Perkembangan penduduk yang tinggi, kebutuhan akan tempat tinggal yang berkemabng pesat dan daya dukung perekonomian, menyebabkan banyak penggunaan lahan yang bersifat konservasi di dalam DAS berubah menjadi lahan terbuka dan terbangun. Perubahan penggunaan lahan tersebut jika tidak terkendali dan tidak didukung oleh upaya konservasi DAS yang baik akan memicu degradasi kualitas DAS, yang disebabkan oleh menurunnya fungsi lahan sebagai wilayah penyangga, baik dari aspek produksi dan ketersediaan air. Untuk itu perlu dilakukan upaya untuk meningkatkan kembali fungsi dan peruntukan lahan tersebut sehingga kualitas DAS kembali dalam kondisi yang seimbang dan lestari.

Peningkatan kualitas DAS dapat dilakukan antara lain melalui program Rehabilitasi Hutan dan Lahan (RHL). Program RHL akan dapat terlaksana dengan baik apabila informasi obyektif kondisi hutan dan lahan sasaran RHL dapat teridentifikasi secara menyeluruh. Penyediaan data dan informasi tersebut sangat diperlukan terutama dalam menunjang formulasi strategi RHL yang berdaya guna, sehingga diharapkan dapat diperoleh acuan dalam pengalokasian sumberdaya secara proporsional. Hasil formulasi strategis tersebut selanjutnya akan mendukung terciptanya daya dukung sumberdaya hutan dan lahan yang optimal dan lestari bagi kesejahteraan manusia.

Penyediaan data dan informasi mengenai kondisi degradasi hutan dan lahan yang disampaikan oleh berbagai pihak, seringkali tidak mengacu kepada format dan struktur basisdata yang dapat dipertanggungjawabkan. Akibatnya, nformasi yang diberikan seringkali kurang akurat dan kurang informatif. Bagi para pengambil kebijakan, keadaan tersebut sangat mengganggu dalam proses pengambilan keputusan (decission making 26 process), dalam arti berdasarkan data dan informasi yang tersedia kecil kemungkinannya diperoleh rekomendasi yang berdaya guna sebagai acuan dalam pengambilan kebijakan.

Berdasarkan ketentuan Pasal 8 Peraturan Pemerintah Nomor 76 Tahun 2008 tentang Rehabilitasi dan Reklamasi Hutan, maka kegiatan rehabilitasi dilakukan di semua hutan dan lahan kritis. Dalam rangka pelaksanaan rehabilitasi sebagaimana disebut di atas, perlu disusun Perencanaan Rehabilitasi Hutan dan Lahan yang mengacu kepada peta dan data lahan kritis tahun terbaru. Peta dan data lahan kritis yang dihasilkan, diharapkan menjadi acuan bagi para pengambil kebijakan (decisionmaker) dalam menyusun program rehabilitasi hutan dan lahan sehingga pada akhirnya dapat meningkatkan daya dukung DAS.

Kabupaten Kulon Progo berada di wilayah Daerah Istimewa Yogyakarta. Wilayah ini termasuk dalam DAS Progo yang secara morfologi berada pada bagian hulu dan tengah. Sebagai wilayah hulu yang merupakan bagian dari lereng G. Merapi, maka wilayah ini merupakan daerah tangkapan hujan yang bertugas mensuplai kebutuhan air dalam DAS tersebut, khususnya untuk daerah Kabupaten Kulon Progo dan sekitarnya. Sebagai wilayah yang merupakan daerah tangkapan hujan maka kelestarian wilayah ini harus dijaga, salah satunya dengan cara mengatur pemanfaatan lahan yang terdapat di wilayah ini. Selain itu secara kontinyu juga harus diketahui kondisi lahan kritis yang ada di daerah hulu ini. 


\section{Rumusan Masalah}

Lahan bagi masyarakat merupakan faktor produksi alam yang dapat dikelola untuk menjadi sumber pendapatan mereka (Callier et al., 1979 dalam Buntoro, 1985). Namun karena sifatnya yang tidak dapat dipindah dan luasnya terbatas, menyebabkan meningkatnya kebutuhan dan persaingan dalam penggunaan lahan baik untuk keperluan pertanian maupun untuk keperluan lainnya.

Mengingat pentingnya lahan bagi kehidupan manusia maka diperlukan pengaturan tentang pemanfaatan lahan guna mempertahankan kelestariannya. Pengaturan tersebut harus didasarkan pada aspek potensi dan kemampuan lahan untuk mendukung pemanfaatannya.

Kabupaten Kulon Progo yang merupakan wilayah yang mempunyai bagian hulu dari DAS Progo, tepatnya yang berada pada lereng merapi, merupakan wilayah yang penting untuk dipertahankan kelestarian lahannya. Kerusakan yang terjadi pada wilayah ini akan besar pengaruhnya terhadap wilayah lain di bawahnya.

Salah satu cara yang dapat dilaksanakan untuk melakukan pengaturan pemanfaatan lahan adalah melihat aspek kekritisan lahan pada wilayah Kabupaten Kulon Progo yang kemudian dibandingkan dengan pemanfaatan lahan eksisting yang ada. Aspek kekritisan lahan tersebut dapat dimodelkan menjadi data spasial dalam bentuk peta lahan kritis.

Sesuai dengan kesepakatan yang ada diantara berbagai stakeholder, maka wali data dari lahan kritis adalah Kemeterian Kehutanan RI. Hal ini berakibat pada metode pemetaan lahan kritis yang diakui dalam penyelenggaraan pemerintahan adalah pedoman lahan kritis yang dikeluarkan oleh Kementerian Kehutanan RI.
Tujuan kegiatan ini adalah untuk :

1. Memetakan lahan kritis yang terdapat di wilayah Kabupaten Kulon Progo menggunakan analisis data spasial dari interpretasi citra penginderaan jauh dan peta-peta tematik yang sudah ada.

2. Menganalisis keterkaitan antara pemanfaatan lahan eksisting terhadap lahan kritis yang ada

\section{Tinjaun Pustaka}

\section{A. Lahan Kritis}

Lahan kritis dalam kegiatan ini didefinisikan sebagai lahan yang keadaan fisiknya menggalami kondisi di mana lahan tersebut tidak dapat berfungsi secara baik sesuai dengan peruntukannya sebagai media produksi maupun sebagai media tata air. Parameter penentu lahan kritis berdasarkan Permenhut Nomor P.32/Menhut-II/2009, meliputi :
a. Penutupan lahan
b. Kemiringan lereng
c. Tingkat bahaya erosi
d. Produktivitas
e. Manajemen

\section{a. Penutupan Lahan}

Parameter penutupan lahan dinilai berdasarkan prosentase penutupan tajuk pohon terhadap luas setiap land unit (hasil interpretasi citra penginderaan jauh) dan diklasifikasikan menjadi lima kelas. Masingmasing kelas penutupan lahan selanjutnya diberi skor untuk keperluan penentuan lahan kritis. Dalam penentuan lahan kritis, parameter penutupan lahan mempunyai bobot 50\%, sehingga nilai skor untuk parameter ini merupakan perkalian antara skor dengan bobotnya (skor x 50). Klasifikasi penutupan lahan dan skor untuk masing-masing kelas ditunjukkan pada tabel berikut. 
Tabel 1. Klasifikasi dan Skoring Penutupan Lahan Untuk Penentuan Lahan Kritis

\begin{tabular}{lccc}
\hline \multicolumn{1}{c}{ Kelas } & Prosentase Penutupan Tajuk (\%) & $\begin{array}{c}\text { Skor } \\
\mathbf{x} \\
\text { Skor } \\
\text { Bobot } \\
\mathbf{( 5 0 )}\end{array}$ \\
\hline Sangat Baik & $>80$ & 5 & 250 \\
Baik & $61-80$ & 4 & 200 \\
Sedang & $41-60$ & 3 & 150 \\
Buruk & $21-40$ & 2 & 100 \\
Sangat Buruk & $<20$ & 1 & 50 \\
\hline
\end{tabular}

\section{b. Kemiringan Lereng}

Kemiringan lereng adalah perbandingan antara beda tinggi (jarak vertikal) suatu lahan dengan jarak mendatarnya. Besar kemiringan lereng dapat dinyatakan dengan beberapa satuan, diantaranya adalah dengan \% (persen) dan - (derajat). Data spasial kemiringan lereng dapat disusun dari hasil pengolahan data

ketinggian (garis kontur) dengan bersumber pada peta topografi atau peta rupa bumi. Pengolahan data kontur untuk menghasilkan informasi kemiringan lereng dapat dilakukan secara manual maupun dengan bantuan komputer. Bobot untuk parameter lereng dalam penyusunan lahan kritis adalah 20.

Tabel 2 Klasifikasi Lereng dan Skoringnya Untuk Penentuan Lahan Kritis

\begin{tabular}{lccc}
\hline Kelas & $\begin{array}{c}\text { Kemiringan } \\
\text { Lereng(\%) }\end{array}$ & Skor & $\begin{array}{c}\text { Skor } \mathbf{x} \\
\text { Bobot }(\mathbf{2 0})\end{array}$ \\
\hline Datar & $<8$ & 5 & 100 \\
Landai & -15 & 4 & 80 \\
Agak Curam & $16-25$ & 3 & 60 \\
Curam & $26-40$ & 2 & 40 \\
Sangat Curam & $>40$ & 1 & 20 \\
\hline
\end{tabular}

c. Tingkat Bahaya Erosi

Tingkat Bahaya Erosi (TBE) dapat dihitung dengan cara membandingkan tingkat erosi di suatu satuan lahan (land unit) dan kedalaman tanah efektif pada satuan lahan tersebut. Dalam hal ini tingkat erosi dihitung dengan menghitung perkiraan rata-rata tanah hilang tahunan akibat erosi lapis dan alur yang dihitung dengan rumus Universal Soil Loss Equation (USLE). Perhitungan Tingkat Erosi dengan rumus USLE Rumus USLE dapat dinyatakan sebagai,

$$
A=\operatorname{R} \times \operatorname{K} \times \operatorname{LS} \times \mathbf{C} \times \mathbf{P}
$$

Dimana:

$\mathrm{A}=$ jumlah tanah hilang (ton/ha/tahun)

$\mathrm{R}=$ erosivitas curah hujan tahunan rata-rata (biasanya dinyatakan sebagai energi dampak curah hujan (MJ/ha) x Intensitas hujan maksimal selama 30 menit $(\mathrm{mm} / \mathrm{jam})$

$\mathrm{K}=$ indeks erodibilitas tanah(ton $\mathrm{x}$ ha $\mathrm{x}$ jam) Dibagi oleh (ha x megajoule $\mathrm{x} \mathrm{mm}$ )

LS =indeks panjang dan kemiringan lereng

$\mathrm{C}=$ indeks pengelolaan tanaman

$\mathrm{P}=$ indeks upaya konservasi tanah 
Tabel 3 Kelas Tingkat Bahaya Erosi

\begin{tabular}{|c|c|c|c|c|c|}
\hline \multirow{4}{*}{$\begin{array}{l}\text { Solum Tanah } \\
(\mathrm{cm})\end{array}$} & \multicolumn{5}{|c|}{ Kelas Erosi } \\
\hline & I & II & III & IV & V \\
\hline & \multicolumn{5}{|c|}{ Erosi (ton/ha/tahunan) } \\
\hline & $<15$ & $15-60$ & $60-180$ & $180-480$ & $>480$ \\
\hline Dalam & SR & $\mathrm{R}$ & $\mathrm{S}$ & B & SB \\
\hline$>90$ & 0 & I & II & III & IV \\
\hline Sedang & $R$ & $\mathrm{~S}$ & $B$ & SB & SB \\
\hline $60-90$ & I & II & III & IV & IV \\
\hline Dangkal & S & B & SB & SB & SB \\
\hline $30-60$ & II & III & IV & IV & IV \\
\hline Sangat Dangkal & B & SB & SB & SB & SB \\
\hline$<30$ & III & IV & IV & IV & IV \\
\hline
\end{tabular}

Keterangan:

o-SR= Sangat Ringan

$\mathrm{I}-\mathrm{R}=$ Ringan

II-S= Sedang

III-B= Berat

$\mathrm{IV}-\mathrm{SB}=$ Sangat Berat

\section{d. Produktivitas}

Data produktivitas merupakan salah satu kriteria yang dipergunakan untuk menilai kekritisan lahan dikawasan budidaya pertanian, yang dinilai berdasarkan ratio terhadap produksi komoditi umum optimal pada pengelolaan tradisional.

Sesuai dengan karakternya, data tersebut merupakan data atribut. Didalam analisa spasial, data atribut tersebut harus

dispasialkan dengan satuan pemetaan land system. Alasan utama digunakannya land system sebagai satuan pemetaan produktivitas adalah setiap land system mempunyai karakter geomorfologi yang spesifik, sehingga mempunyai pola usaha tani dan kondisi lahan yang spesifik pula.

Produktivitas lahan dalam penentuan lahan kritis dibagi menjadi 5 kelas seperti terlihat pada Tabel 4 . berikut ini.

Tabel 4 Klasifikasi Produktivitas dan Skoringnya Untuk Penentuan Lahan Kritis

\begin{tabular}{|c|c|c|c|}
\hline Kelas & Besaran/Deskripsi & Skor & $\begin{array}{c}\text { Skor x } \\
\text { Bobot } \\
(30)\end{array}$ \\
\hline $\begin{array}{l}\text { Sangat } \\
\text { Tinggi }\end{array}$ & $\begin{array}{l}\text { Ratio terhadap produksi komoditi umum optimal pada } \\
\text { pengelolaan tradisional: }>80 \%\end{array}$ & 5 & 150 \\
\hline Tinggi & $\begin{array}{l}\text { Ratio terhadap produksi komoditi umum optimal pada } \\
\text { pengelolaan tradisional: } 61-80\end{array}$ & 4 & 120 \\
\hline Sedang & $\begin{array}{l}\text { Ratio terhadap produksi komoditi umum optimal pada } \\
\text { pengelolaan tradisional: } 4 \mathbf{1}-60 \%\end{array}$ & 3 & 90 \\
\hline Rendah & $\begin{array}{l}\text { Ratio terhadap produksi komoditi umum optimal pada } \\
\text { pengelolaan tradisional: } 2 \mathbf{2 1}-40 \%\end{array}$ & 2 & 60 \\
\hline $\begin{array}{l}\text { Sangat } \\
\text { Rendah }\end{array}$ & $\begin{array}{l}\text { Ratio terhadap produksi komoditi umum optimal pada } \\
\text { pengelolaan tradisional: }<20 \%\end{array}$ & 1 & 30 \\
\hline
\end{tabular}




\section{e. Manajemen}

Manajemen merupakan salah satu kriteria yang dipergunakan untuk menilai lahan kritis dikawasan hutan lindung, yang dinilai berdasarkan kelengkapan aspek pengelolaan yang meliputi keberadaan tata batas kawasan, pengamanan dan pengawasan serta dilaksanakan atau tidaknya penyuluhan. Sesuai dengan karakternya, data tersebut merupakan data atribut. Seperti halnya dengan kriteria produktivitas, manajemen pada prinsipnya merupakan data atribut yangberisi informasi mengenai aspek manajemen. Berkaitan dengan penyusunan data spasial lahan kritis, kriteria tersebut perlu dispasialisasikan dengan menggunakan atau berdasar pada unit pemetaan tertentu. Unit pemetaan yang digunakan, mengacu pada unit pemetaan untuk kriteria produktivitas, adalah unit pemetaan land system. Kriteria manajemen dalam penentuan lahan kritis dibagi menjadi 3 kelas seperti terlihat pada Tabel 5 . berikut ini.

Tabel 5 Klasifikasi Manajemen dan Skoringnya untuk Penentuan Lahan Kritis

\begin{tabular}{cccc}
\hline Kelas & Besaran/ Deskripsi & Skor & Skor x Bobot (10) \\
\hline Baik & Lengkap $\left.{ }^{*}\right)$ & 5 & 50 \\
Sedang & Tidak Lengkap & 3 & 30 \\
Buruk & Tidak Ada & 1 & 10 \\
\hline
\end{tabular}

*):-Tata batas kawasan ada

-Pengamanan pengawasan ada

-Penyuluhan dilaksanakan

Analisis spasial dilakukan dengan menumpangsusunkan (overlay) beberapa data spasial (parameter penentu lahan kritis) untuk menghasilkan unit pemetaan baru yang akan digunakan sebagai unit analisis. Pada setiap unit analisis tersebut dilakukan analisis terhadap data atributnya yang tak lain adalah data tabular, sehingga analisisnya disebut juga analisis tabular. Hasil analisis tabular selanjutnya dikaitkan dengan data spasialnya untuk menghasilkan data spasial lahan kritis.

\section{f. Analisis Spasial Lahan Kritis}

Metode yang digunakan dalam analisis tabular adalah metode skoring. Setiap parameter penentu lahan kritis diberi skor tertentu seperti telah dijelaskan pada bagian I dari petunjuk teknis ini. Pada unit analisis hasil tumpang susun data spasial, skor tersebut kemudian dijumlahkan. Hasil penjumlahan skor selanjutnya diklasifikasikan untuk menentukan tingkat lahan kritis. Klasifikasi tingkat lahan kritis berdasarkan jumlah skor parameter lahan kritis seperti ditunjukkan pada Tabel 6 .

Tabel 6 Klasifikasi Tingkat Lahan kritis Berdasarkan Total Skor

\begin{tabular}{cccc}
\hline $\begin{array}{c}\text { Kawasan Hutan } \\
\text { Lindung }\end{array}$ & $\begin{array}{c}\text { Kowasan Budidaya } \\
\text { Pertanian }\end{array}$ & $\begin{array}{c}\text { Kawasan Lindung } \\
\text { di luar Kawasan } \\
\text { Hutan }\end{array}$ & $\begin{array}{c}\text { Tingkat Lahan } \\
\text { kritis }\end{array}$ \\
\hline $120-180$ & $115-200$ & $110-200$ & Sangat Kritis \\
$181-270$ & $201-275$ & $201-275$ & Kritis \\
$271-360$ & $276-350$ & $276-350$ & Agak Kritis \\
$361-450$ & $351-425$ & $351-425$ & Potensial Kritis \\
$451-500$ & $426-500$ & $426-500$ & Tidak Kritis \\
\hline
\end{tabular}




\section{B. Penginderaan Jauh}

Penginderaan jauh adalah ilmu atau seni untuk memperoleh informasi tentang suatu obyek, daerah, atau gejala melalui analisis data yang diperoleh dengan suatu alat tanpa kontak langsung dengan obyek, daerah, atau gejala yang dikaji (Lillesand et al., 2004). Alat yang dimaksud adalah sensor penginderaan jauh yang menerima dan merekam tenaga yang datang dari obyek di permukaan bumi. Tiap sensor mempunyai kepekaan tersendiri terhadap bagian spektrum elektromagnetik yang mengenainya.

Tiap obyek di permukaan bumi mempunyai ciri tersendiri dalam menyerap, memantulkan dan meneruskan tenaga yang diterimanya. Pada panjang gelombang $0,55 \mu \mathrm{m}$ (saluran hijau) terdapat puncak kecil karena kloroplas memantulkan sebagian besar sinar hijau yang diterimanya. Pada saluran biru $(0,45 \mu \mathrm{m})$ dan saluran merah $(0,65 \mu \mathrm{m})$ terjadi serapan energi oleh kloroplas yang digunakan untuk fotosintesis. Pada saluran dengan panjang gelombang lebih besar dari o,70 $\mu \mathrm{m}$ (inframerah dekat) terjadi kenaikan pantulan yang sangat tajam, karena sinar inframerah dekat dipantulkan oleh jaringan parensima daun (spongy mesophyl). Konsep tersebut berlaku untuk vegetasi secara umum dan dalam kondisi sehat.

Menurut Hoffer (dalam Swain dan Davis, 1978) pantulan daun berlapis banyak (multiple leaf layers) lebih besar $85 \%$ dibandingkan pantulan pada daun berlapis tunggal (single leaf layers) pada saluran inframerah dekat. Penyebab lebih besarnya pantulan pada daun berlapis banyak adalah adanya tambahan sinar pantulan yang berasal dari sinar yang diteruskan oleh lapisan yang ada di bawahnya. Kerapatan daun juga mempunyai pengaruh terhadap pantulan spektral, dimana semakin rapat kanopi maka semakin luas permukaan daun yang bertindak sebagai pemantul. Pada spektrum inframerah dekat daun hijau cenderung lebih banyak memantulkan dan meneruskan energi yang diterimanya.

\section{METODE}

\section{A. Bahan}

Bahan peneltian yang digunakan dalam kegiatan ini adalah sebagai berikut :

1. Citra ALOS AVNIR-2 KabupatenKulon Progo

2. Peta Penggunaan Lahan KabupatenKulon Progo

3. Peta Bentuklahan KabupatenKulon Progo

4. Peta Hidrologi KabupatenKulon Progo

5. Peta Jenis Tanah KabupatenKulon Progo

6. Peta Kemiringan Lereng KabupatenKulon Progo

7. Peta Iklim KabupatenKulon Progo

B. Alat

Alat yang digunakan dalam penelitian ini adalah sebagai berikut :

1. Seperangkat komputer Dual Core 2,2 Ghz, RAM 2 GB, HDD 320 GB untuk pengolahan data dan penulisan laporan penelitian.

2. Printer HP Desksjet D2466 untuk mencetak hasil penelitian.

3. Software untuk mengolah citra dan data SIG

4. GPS (Global Positioning System) untuk pengeplotan data lapangan.

5. Kuisioner untuk mengetahui kondisi lapangan

6. Kamera Digital untuk dokumentasi

7. Alat tulis untuk mencatat selama penelitian

\section{Prosedur penyusunan peta lahan kritis}

Prosedur penyusunan petunjuk teknis penyusunan data spasial lahan kritis mengikuti alur pikir seperti disajikan pada Gambar 1. Sedangkan prosedur penentuan lahan kritis menurut Peraturan Menteri Kehutanan Nomor.P.32/Menhut- II/2009, sebagaimana disajikan pada Gambar 7. 


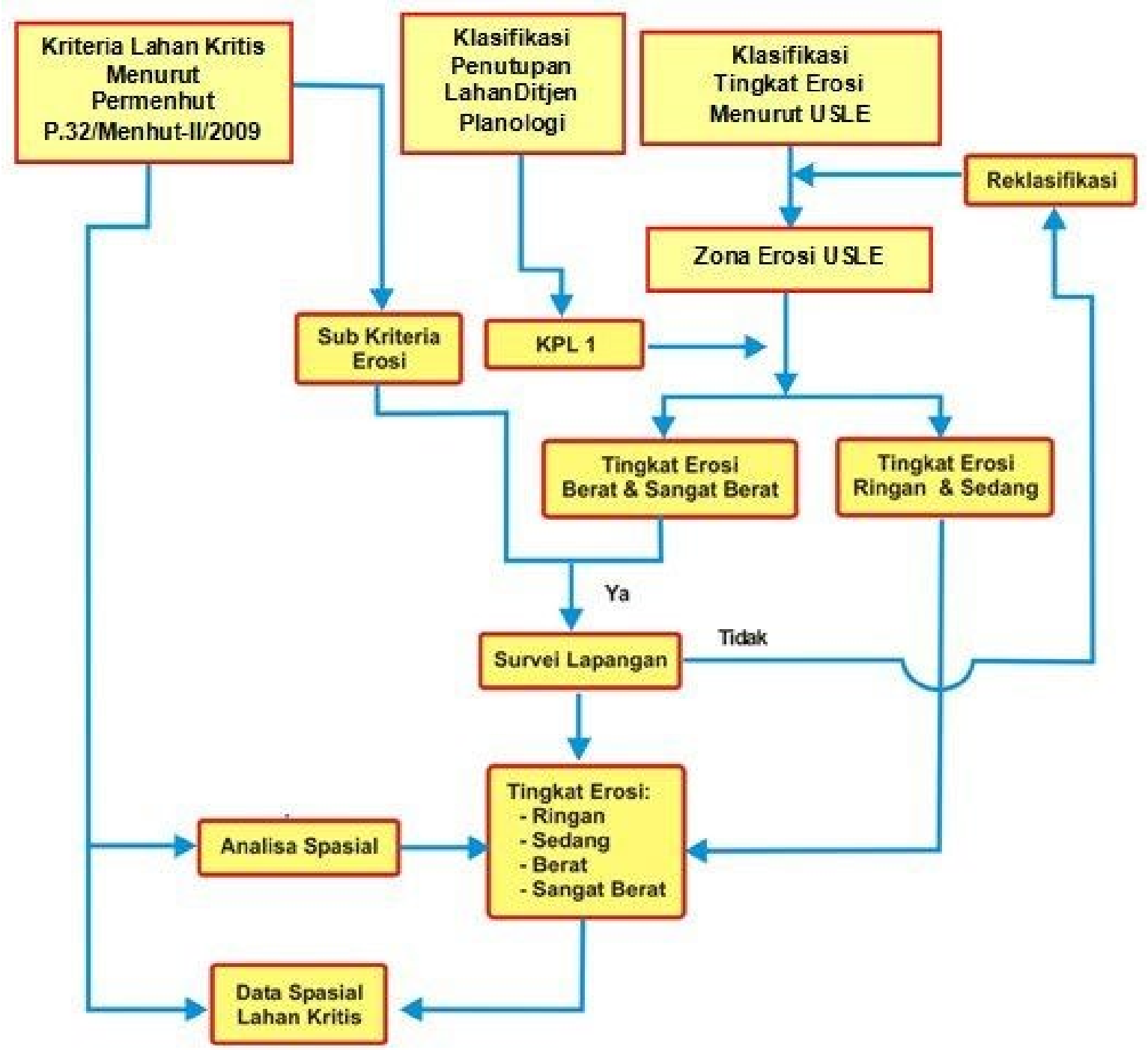

Gambar 7 Alur Pikir Penyusunan Data Spasial Lahan Kritis 


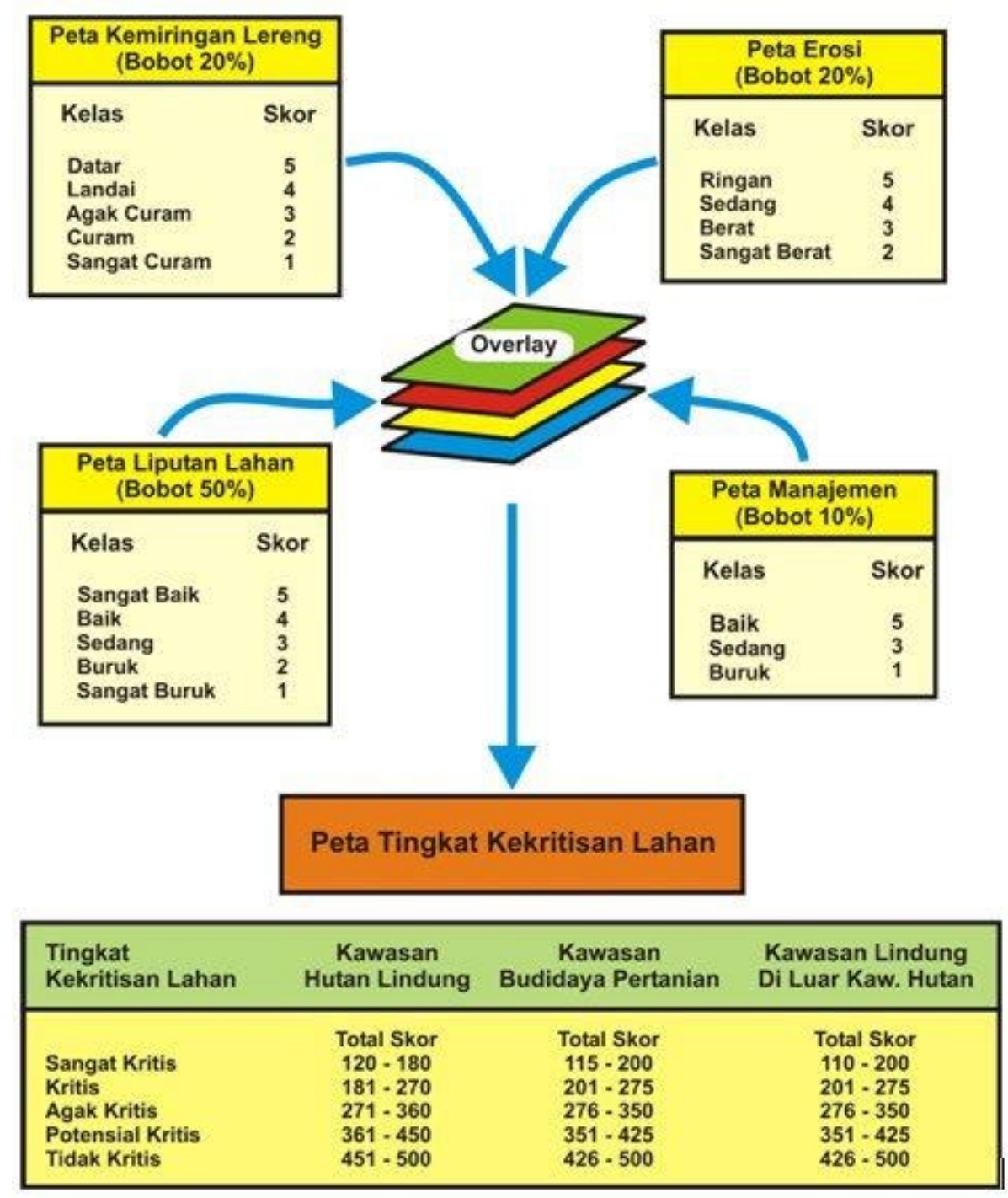

Gambar 8 Diagram Alir Penentuan Tingkat Lahan Kritis

Guna memungkinkan analisis yang lebih luas untuk kepentingan rehabilitasi hutan dan lahan, scoring lahan kritis dalam Permenhut No. P.32/Menhut-II/2009 perlu diperluas mencakup seluruh fungsi hutan dan di luar kawasan hutan sebagai berikut:

a. Total skor untuk kawasan hutan lindung dapat disetarakan untuk kawasan hutan konservasi

b. Total skor untuk kawasan budidaya pertanian dapat disetarakan untuk areal penggunaan lain (di luar kawasan hutan)

c. Total skor untuk kawasan lindung di luar kawasan hutan dapat disetarakan untuk kawasan hutan produksi (hutan produksi tetap, hutan produksi yang dapat dikonversi dan hutan produksi terbatas).
Setelah diperoleh data lahan kritis maka langkah selanjutnya adalah menunpangsusunkan peta lahan kritis dengan peta penggunaan lahan eksisting. Dari hasil tumpangsusun tersebut akan disusun kesesuaian pemanfaatan lahan yang ada pada saat ini dengan kekritisan lahannya. Asumsi yang dibangun dalam menilai kesesuaian tersebut adalah pemanfaatan lahan yang produktif seyogyanya dilakukan pada lahan yang tidak kritis, sementara untuk lahan yang kritis sebaiknya digunakan untuk pemanfaatan lahan yang sifatnya konservasi. 


\section{HASIL DAN PEMBAHASAN}

Seperti telah diuraikan pada bagian metode, pemetaan lahan kritis di Kabupaten Kulon Progo ini menggunakan metode pemetaan lahan kritis yang terdapat dalam pedoman penyusunan peta lahan kritis yang dibuat oleh Direktorat PEPDAS Kemeterian Kehutanan RI. Penggunaan lahan yang beragam di Kulon Progo memberikan kontribusi pada jumlah kelas kekritisan lahan yang ada (Gambar 9).

Hasil pemetaan lahan kritis di Kabupaten Kulon Progo menunjukkan bahwa $16.7 \%$ atau 9541,21 ha dari luas wilayah kabupaten tersebut merupakan lahan yang tidak kritis, sedangkan $47.8 \%$ atau 27.397 ha merupakan lahan yang potensial kritis, atau jika tidak dikelola dengan baik bisa menjadi lahan kritis; dan $35,5 \%$ atau 20,329 ha merupakan wilayah dengan status kekritisan lahan dari agak kritis, kritis hingga sangat kritis. Hal ini menunjukkan bahwa wilayah Kabupaten Kulon Progo ini mempunyai kondisi biogeofisik yang masih cukup bagus karena didominasi lahan yang tidak kritis, namun perlu pengelolaan lahan yang lebih intensfi untuk mencegah terjadinya keritisan lahanyang lebih lanjut, dan memremediasi lahan-lahan yang sudah dianggap kritis. Sebaran dari lahan potensial kritis dan tidak kritis di wilayah Kabupaten Kulon Progo disajikan pada gambar 10

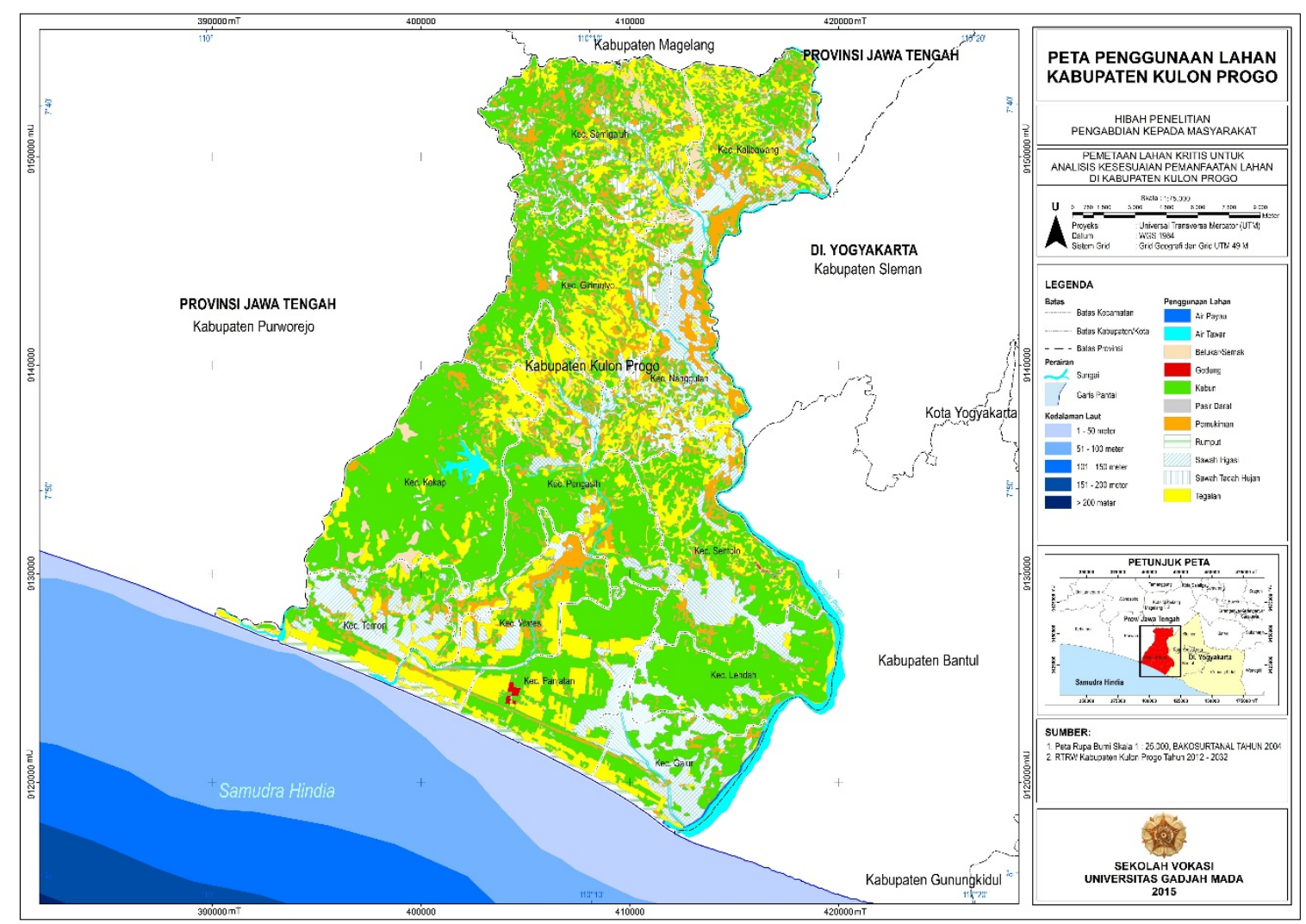

Gambar 9 Peta Penggunaan Lahan Kabupaten Kulon Progo 
Terkait dengan pemanfaatan lahan eksisiting yang ada, sebaran dari lahan yang potensial kritis tersebut terutama berada di sepanjang aliran Sungai Progo dan serang yang dimanfaatkan oleh penduduk sebagai lokasi penambangan pasir, dan juga di wilayah yang memiliki kemiringan lereng cukup tinggi. Sebagian lainnya tersebar merata di seluruh wilayah Kabupaten Kulon Progo, terutama pada penggunaan lahan rumput dan tegalan. Hal ini perlu mendapat perhatian dan penanganan yang tepat, karena jika dibiarkan akan berpotensi untuk meningkatkan status lahannya dari potensial kritis menjadi lahan kritis. Apalagi wilayah Kabupaten Kulon Progo merupakan bagian dari wilayah hulu DAS Progo yang mempunyai fungsi sebagai daerah tangkapan hujan yang harus dipertahankan kelestariannya.

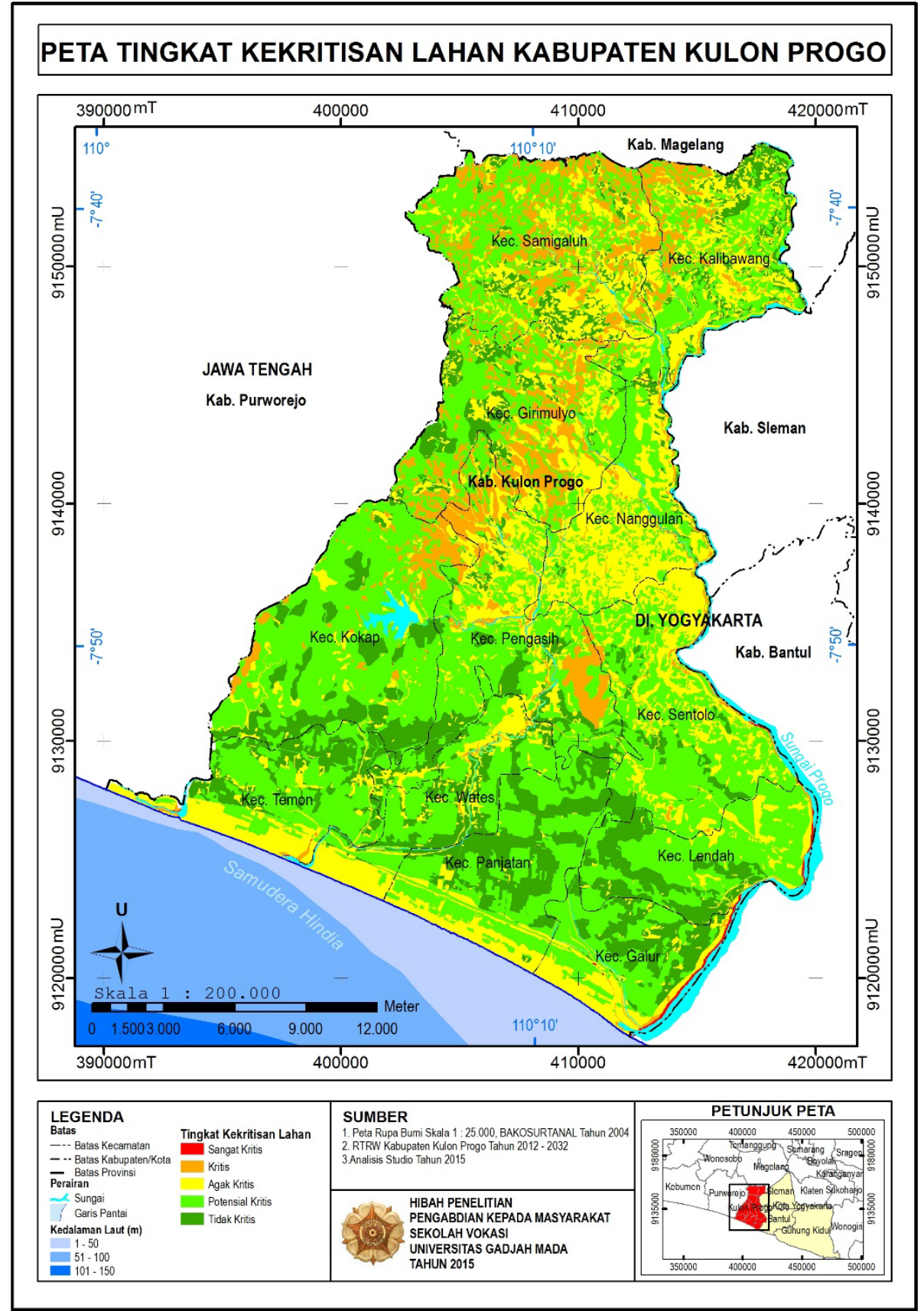

Gambar 10. Peta tingkat kekritisan lahan Kabupaten Kulon Progo 


\section{SIMPULAN}

Wilayah-wilayah yang potensial kritis, terutama di sepanjang aliran S. Progo dan Serang, dan juga wilayah yang memiliki kemiringan lereng tinggi perlu mendapatkan perhatian serius karena wilayah tersebut mempunyai penutup lahan pasir darat yang menjadi areal penambangan pasir oleh masyarakat. Penambangan yang tidak terkendali akan meningkatkankan status lahannya menjadi lahan kritis.

Wilayah Kabupaten Kulon Progo termasuk dalam wilayah hulu DAS Opak yang berfungsi sebagai daerah tangkapan hujan, namun sebagian besar wilayahnya mempunyai penggunaan lahan pertanian (sawah dan sawah tadah hujan). Perlu dilakukan rekayasa untuk mempertahankan fungsi resapannya melalui pembuatan biopori, sumur resapan, cemplongan, dan sebagainya.

\section{DAFTAR PUSTAKA}

Anonim. (2014). AVNIR-2 Major Characteristics. http://www.alosrestec.jp/ en/staticpages/ index.php/ Avnir-2

Anonim. (2014).

ENVI.

http://www.exelisvis.com/

ProductServices/ENVI/ENVI.aspx

Anonim. (2008). Peraturan Pemerintah

Nomor 76 Tahun 2008 tentang Rehabilitasi dan Reklamasi Hutan, Kementerian Kehutanan RI

Anonim. (2009). Peraturan Menteri Kehutanan Nomor P.32/MenhutII/2009 Tentang Pedoman Penyusunan Lahan Kritis, Kemeterian Kehutanan RI

Anonim. (2012). Peraturan Pemerintah Nomor 37 Tahun 2012 tentang Pengelolaan DAS, Kementerian Kehutanan RI

Buntoro. (1985). Kajian Distribusi Pemilikan Lahan dan Pendapatan Petani Pedukuhan Kayongan Kalurahan Sabdodadi Bantul, Skripsi, Fakultas Geografi UGM, Yogyakarta
Howard, John. A. (1993). Penginderaan Jauh untuk Sumberdaya Hutan (terjemahan), Gama Press, Yogyakarta Ormsby, J.P., Choundhury, B.J., and Owe, M. (1987). Vegetation Spatial Variability and Its Effect on Vegetation Indices, in International Journal of Remote Sensing Vol. 8 No. 9

Projo Danoedoro. (1993). The Use of Kwonledge-Based Approaches in The Integration of Remote Sensing and Geographic Information System for Land Use Mapping, A Case Study of Buffer Zone of Cibodas Biosphere Reserve, M.Sc. Thesis, ITC, Enschede, The Netherlands

Sigit Herumurti. (1997). Estimasi Produksi Daun Tembakau Berdasarkan Integrasi Pengolahan Citra Landsat Thematic Mapper Dengan Sistem Informasi Geografis, Skripsi, Fakultas Geografi UGM, Yogyakarta

Swain, Philip H., and Davis, Shirley M. (1978). Remote Sensing : The Quantitative Approach, McGraw-Hillb International Book Company. 